\title{
Physicians' attitudes and practice toward treating injection drug users infected with hepatitis $C$ virus: Results from a national specialist survey in Canada
}

\author{
Angelique Myles MSc ${ }^{1}$, Gerry J Mugford BSc PhD ${ }^{2}$, Jing Zhao MSc ${ }^{1}$, \\ Murray Krahn MD MSC FRCPC ${ }^{3,4}$, Peizhong Peter Wang MD MPH PhD ${ }^{1,5}$
}

\begin{abstract}
A Myles, GJ Mugford, J Zhao, M Krahn, PP Wang. Physicians' attitudes and practice toward treating injection drug users infected with hepatitis $\mathrm{C}$ virus: Results from a national specialist survey in Canada. Can J Gastroenterol 2011;25(3):135-139.
\end{abstract}

BACKGROUND: In Canada, more than $70 \%$ of new cases of hepatitis $\mathrm{C}$ virus (HCV) infection per year involve injection drug users (IDUs) and, currently, there is no consensus on how to offer them medical care.

OBJECTIVE: To examine the characteristics of Canadian specialist physicians and their likelihood to provide treatment to $\mathrm{HCV}$ patients who are IDUs.

METHODS: A nationwide, cross-sectional study was conducted in the specialty areas of hepatology, gastroenterology and infectious diseases to examine HCV services. The questionnaire requested information regarding basic demographics, referral pathways and opinions (yes/no), and examined how a physician's treatment regimen is influenced by factors such as treatment eligibility, HCV care management and barriers to providing quality service.

RESULTS: Despite the fact that the majority of prevalent and incident cases of HCV are associated with injection drug use, very few specialist physicians actually provide the necessary therapy to this population. Only 19 (19.79\%) comprehensive service providers were likely to provide treatment to a current IDU who uses a needle exchange on a regular basis. The majority of comprehensive service providers $(n=86[89.58 \%]$ ) were likely to provide treatment to a former IDU who was stable on substitution therapy. On bivariate analysis, factors associated with the likelihood to provide treatment to current IDUs included physicians' type, ie, infectious disease specialists compared with noninfectious specialists (OR 3.27 [95\% CI 1.11 to 9.63]), and the size of the community where they practice (OR 4.16 [95\% CI 1.36 to 12.71] [population 500,000 or greater versus less than $500,000])$. Results of the multivariate logistic regression analysis were largely consistent with the results observed in the bivariate analyses. After controlling for other confounding variables, only community size was significantly associated with providing treatment to current IDUs (OR 3.89 [95\% CI 1.06 to 14.26] [population 500,000 or greater versus less than 500,000]).

CONCLUSION: The present study highlighted the reluctance of specialists to provide treatment to current IDUs infected with HCV. Providing treatment services for HCV-infected substance abusers is challenging and there are many treatment barriers. However, effective delivery of treatment to this population will help to limit the spread of $\mathrm{HCV}$. The present study clearly identified a need for improved HCV treatment accessibility for IDUs.

Key Words: Hepatitis C; Injection drug user; Physician survey

\author{
Les attitudes et la pratique des médecins envers le \\ traitement des consommateurs de drogues par \\ injection infectés par le virus de l'hépatite $\mathrm{C}$ : \\ les résultats d'un sondage national auprès de \\ spécialistes du Canada
}

HISTORIQUE : Au Canada, plus de $70 \%$ des nouveaux cas d'infection par le virus de l'hépatite $\mathrm{C}$ (VHC) par année sont des consommateurs de drogues injectables (CDI). Il n'y a pas de consensus pour l'instant sur la manière de leur offrir des soins médicaux.

OBJECTIF : Examiner les caractéristiques des médecins spécialistes canadiens et la probabilité qu'ils dispensent un traitement aux patients ayant un VHC qui sont des CDI.

MÉTHODOLOGIE : Les chercheurs ont mené une étude transversale nationale dans les domaines de spécialité de l'hépatologie, de la gastroentérologie et de l'infectiologie afin d'examiner les services sur le VHC. Le questionnaire comprenait des questions sur les données démographiques de base, les voies d'aiguillage et les opinions (oui ou non) et permettait d'évaluer à quel point le schéma thérapeutique d'un médecin est influencé par des facteurs comme l'admissibilité au traitement, la prise en charge des soins du VHC et les obstacles à offrir des services de qualité. RÉSULTATS : Même si la majorité des cas prévalents et incidents de VHC s'associent à la consommation de drogues injectables, très peu de médecins spécialistes dispensent la thérapie nécessaire à cette population. Seulement 19 (19,79\%) dispensateurs de soins complets étaient susceptibles de traiter un CDI qui utilise des services d'échange de seringues sur une base régulière. La majorité des dispensateurs de soins complets ( $\mathrm{n}=86$ [89,58 \%]) étaient susceptibles de traiter un ancien CDI stabilisé par un traitement de substitution. D'après l'analyse bivariée, les facteurs associés à la probabilité de dispenser un traitement aux CDI incluaient le type de médecin, c'est-à-dire les spécialistes en infectiologie par rapport aux autres spécialistes (RRR 3,27 [95 \% IC 1,11 à 9,63]) et la dimension de la collectivité où ils exercent (RRR 4,16 [95\% IC 1,36 à 12,71] [population de 500000 habitants ou plus par rapport à population de moins de 500000 habitants]). Les résultats de l'analyse de régression logistique multivariée étaient largement conformes à ceux observés dans les analyses bivariées. Après contrôle des autres variables confusionnelles, seule la dimension de la collectivité avait un lien significatif avec l'administration d'un traitement aux CDI (RRR 3,89 [95 \% IC 1,06 à 14,26 ] [population de 500000 habitants ou plus par rapport à population de moins de 500000 habitants]).

CONCLUSION : La présente étude a fait ressortir l'hésitation à dispenser un traitement aux CDI infectés par le VHC. Il est difficile d'offrir des services thérapeutiques aux consommateurs de drogues infectés par le VIH, et on constate beaucoup d'obstacles au traitement. Cependant, la prestation efficace du traitement à cette population contribuera à limiter la propagation du VHC. La présente étude a clairement établi la nécessité d'améliorer l'accessibilité au traitement du VHC pour les CDI.

${ }^{1}$ Division of Community Health and Humanities; ${ }^{2}$ Clinical Epidemiology Graduate Medicine Program, Faculty of Medicine, Memorial University of Newfoundland, St John's, Newfoundland and Labrador; ${ }^{3}$ Department of Medicine and Faculty of Pharmacy; ${ }^{4}$ Toronto Health Economics and Technology Assessment Collaborative, University of Toronto, Toronto, Ontario; ${ }^{5}$ School of Public Health, Tianjin Medical University, Tianjin, China

Correspondence and reprints: Dr Peizhong Peter Wang, Division of Community Health and Humanities, Memorial University of Newfoundland, 300 Prince Philip Drive, St John's, Newfoundland and Labrador A1B 3V6. Telephone 709-777-6666, fax 709-777-7382, e-mail pwang@mun.ca Received for publication May 2, 2010. Accepted August 27, 2010 
Tnjection drug use is the leading risk factor for hepatitis $\mathrm{C}$ virus (HCV) infection in industrialized countries $(1,2)$. The risk of transmission is associated with sharing injection equipment including needles, syringes, spoons, cottons and other injection paraphernalia (3). Several recent studies (4-7) have shown that injection drug users (IDUs) can be treated effectively, with treatment success rates that are similar to other patients. Nevertheless, treatment rates are low, and it has been suggested that only approximately 10\% of HCV-infected IDUs who are possible candidates for treatment are actually treated (8-9). It has also been shown that $70 \%$ to $80 \%$ of $\mathrm{HCV}$-infected IDUs have expressed interest in being treated $(10,11)$.

Currently, North American guidelines (12) state that treatment for HCV should be considered on a case-by-case basis and that it is not justifiable to exclude HCV-infected IDUs from antiviral therapy. However, there is no clear understanding of the associated factors that determine whether a specialist will provide treatment to HCV-infected substance abusers. To develop comprehensive strategies to address the $\mathrm{HCV}$ epidemic, it is important to understand physician criteria associated with $\mathrm{HCV}$-related practice patterns. Thus, an inaugural nationwide survey was conducted to examine $\mathrm{HCV}$ treatment eligibility criteria for physicians trained in the specialties of infectious diseases, gastroenterology and hepatology. This particular group represents the majority of physicians providing treatment to people living with HCV.

The objectives of the present study were to describe the clinical practice patterns in treating $\mathrm{HCV}$-infected IDUs and to examine the factors that influence a specialist's likelihood to provide treatment to HCV-infected IDUs.

\section{Study design and participants}

\section{METHODS}

The present study included 528 medical specialists who were most likely to provide care to patients with HCV infection. The sample was obtained using the following two approaches. First, a comprehensive search of the most recent version of the Canadian Medical Directory on CD-ROM [13], which contains information for approximately 61,000 currently practising Canadian physicians, was undertaken. Based on their practices, physicians were grouped according to their main specialties (one or more). The Canadian Medical Directory allows searches of up to 60 specialties (eg, cardiology and rheumatology) and 45 subspecialties (eg, diabetes, pain management and hepatology). Thus, a systematic search was conducted in the specialties of gastroenterology, infectious diseases, endocrinology and pediatrics, searching for text with any mention of hepatology, hepatitis or liver disease in their specialty description. Second, because it was likely that gastroenterologists (GIs) or infectious disease specialists (IDs) treating HCV may be missed in a key word search, it was decided to also include everyone under these two categories even though some of them may have not treated HCV patients. The final sample included GIs, hepatologists and IDs. The selected physicians associated with these specialities were required to speak and/or read English.

\section{Survey instrument and data collection}

The 14-page, self-completed questionnaire was adapted from modifications from research conducted by Parkes et al (14) and included items designed to assess the workload, configuration and care processes of services in Canada to manage patients living with HCV. For the present study, the sample population was divided into three groups based on the type of service the physicians provided. Respondents were asked to choose from the following three categories: no role in the management and diagnosis of patients with $\mathrm{HCV}$; diagnosis with or without initial investigations followed by referral to dedicated HCV service (diagnostic investigative provider [DIP]); and provision of a dedicated HCV service such as diagnosis, investigation, treatment and follow-up (comprehensive service provider [CSP]). Surveys were mailed to 528 physicians at their practice sites. A prenotification letter was sent one week before the survey package to notify the respondents of the study. The first letter, which introduced the participants to the study, was mailed on January 25, 2007. The letter contained information outlining the objectives of the study as well as the affirmation of confidentiality and how informed consent was obtained. This was followed by the survey package, which was sent on January 31, 2007. Questionnaires were assigned code numbers and mailed with a cover letter to each potential respondent.

Participants were asked specific questions about providing treatment to IDUs. One question asked, "Which of the following criteria do you consider in determining eligibility for treatment?" History of substance use/abuse was included in the list. Another question asked, "Which of the following patients with moderate/severe chronic hepatitis $\mathrm{C}$ are likely to receive treatment in your clinical practice? Please tick all that apply." The list included continuing IDUs who regularly use needle exchanges, and ex-IDUs stable on substitution therapy. If the respondent indicated that they would provide treatment to the ex-IDUs stable on substitution therapy, they were asked to indicate how long the patient was required to be stable. They were also asked, "What were the main reasons for patients' ineligibility?" Ongoing illicit drug abuse was included in the list of options.

Current IDUs were defined as individuals who had injected drugs in the past six months and persons with a history of substance use/abuse whose most recent injection occurred more than six months previously. Potential predictors of CSPs' characteristics included physicians' practice region (Atlantic, central, prairies or western Canada), physician type (hepatologist, GI or ID), age, sex, years in practice, size of community where they practice and practice type (eg, solo practice, multiple specialty group, academic and other). To permit meaningful comparisons, the variables were collapsed into broader groups in bivariate and multivariate logistic regression analyses. All analyses were performed using SAS version 9.1 (SAS Institute, USA).

\section{Ethics}

The Human Investigation Committee of the Faculty of Medicine, Memorial University of Newfoundland (St John's, Newfoundland and Labrador) approved the present study.

\section{Response rate}

\section{RESULTS}

Of 528 eligible physicians, 222 returned completed questionnaires. The physician type of the 222 respondents were as follows: 119 GIs (54\%), 78 IDs (35\%) and 25 hepatologists (11\%). Of the GIs, IDs and hepatologists who were sent a survey, $38.6 \%, 48.1 \%$ and $43.1 \%$, respectively, replied. The overall response rate was approximately $42 \%$. There was no significant difference between respondents and nonrespondents among the three types of specialists. Of the 222 respondents, $53(23.9 \%)$ stated that they had no role in the management and diagnosis of HCV patients; 73 (32.8\%) stated that they diagnosed and/or initially investigated $\mathrm{HCV}$ infection, then referred $\mathrm{HCV}$ patients to dedicated HCV service providers; and 96 (43.3\%) reported that they provided dedicated HCV service to patients.

\section{Sociodemographic characteristics of HCV health care providers} The majority of the DIPs (56.16\%) and CSPs (46.88\%) were distributed in central Canada (Ontario and Quebec). The 73 DIPs included 35 GIs $(47.9 \%), 35$ IDs $(47.9 \%)$ and three hepatologists $(4.1 \%)$. The 96 CSPs consisted of 53 GIs (55.2\%), 22 IDs (22.9\%) and 21 hepatologists $(21.9 \%)$. The age range most represented by DIPs and CSPs was 40 to 49 years. Men represented $66.7 \%$ of the DIPs and $82.1 \%$ of the CSPs. Most of the DIPs had practised for 10 to 19 years, and CSPs had practised for more than 10 years. Both DIPs and CSPs practised in a community with a population of 100,000 to more than 500,000 . The main practice type of DIPs was academic compared with most CSPs, who were in solo practices. The detailed sociodemographic characteristics of HCV health care providers are summarized in Table 1.

The associations between the sociodemographic characteristics of CSPs and the likelihood to provide treatment to current IDUs infected with HCV are shown in Table 2. Only 19 CSPs (19.79\%) were likely to provide treatment to a current IDU who uses a needle exchange on a regular basis. In bivariate analysis, factors associated with willingness 
to provide treatment to current IDUs included physician type, ie, IDs versus non-IDs (OR 3.27 [95\% CI 1.11 to 9.63]), size of community where they practice (OR 4.16 [95\% CI 1.36 to 12.71] [population 500,000 or greater versus less than 500,000]). Eighty-six CSPs $(89.58 \%)$ were likely to provide treatment to a person with a history of substance use/abuse who was stable on substitution therapy. The results from the multivariate logistic regression analyses were consistent with the bivariate analyses with respect to direction and magnitude of the associations. Only community size was significantly associated with providing treatment to current IDUs (OR $3.89[95 \%$ CI 1.06 to 14.26 ] [population 500,000 or greater versus less than $500,000])$ after controlling for other confounding variables. The factors associated with providing treatment to persons with a history of substance abuse/use who were stable on substitution therapy were further examined and did not result in statistically significant findings (Table 3).

\section{DISCUSSION}

The current study evaluating the willingness of specialists to provide treatment to IDUs with HCV was unique. The majority of physicians who responded to the survey indicated that they would not provide HCV treatment to a current IDU who used a needle exchange on a regular basis. Low treatment uptake rates were also reported in other studies $(15,16)$, even in HCV populations with no history of injection drug use. This pattern persists despite increasing evidence that IDUs have simliar compliance and treatment-response rates when compared with non-IDUs $(5,7,17-20)$.

Results of the present study suggest that the majority of specialists (89.58\%) were willing to treat a former IDU who was stable on substitution therapy. However, these specialists would prefer that the patient was stable on substitution therapy for at least six months before they provided treatment. This expectation may be a result of the rule that patients must be free of recreational drug use for as long as six months before being considered for HCV therapy in some Canadian centres (21). This finding is consistent with one study (22) that revealed that most physicians withheld treatment from HCV-infected alcoholics or IDUs until a six-month period of abstinence had been achieved. However, some researchers (23) deem this to be an impractical condition considering the fact that patients with substance abuse disorders are subject to relapse.

In the present study, IDs reported a greater likelihood to provide treatment to current IDUs. The willingness of specialists to provide treatment can be influenced by environment-, patient- and diseaserelated factors. Many studies have indicated that potential factors such as patient motivation and adherence (24), ongoing illicit drug/alcohol misuse, HCV RNA levels, fibrosis, hepatitis severity, comorbidities, psychosocial issues, susceptibility to side effects, risk of reinfection (25-27), insurance, access of service and patients' willingness to accept treatment (28), all influence a physician's decision on whether to provide treatment. A study conducted in Australia (23) reported that many physicians believed that HCV treatment should not be provided to IDUs because of concerns regarding adverse effects, adherence to treatment and reinfection with HCV. Fears such as compliance and reinfection surrounding provision of treatment to IDUs are not well substantiated, and it has been shown that IDUs can endure and benefit from HCV treatment (7). Several studies (11,29-31) have shown no association between HCV treatment uptake and injection drug use. Therefore, it is important to assess each HCV-infected substance abuser individually because they differ considerably from one another. Finally, results of the present study suggest a need to focus on complicated environment-, patient-, disease- and physician-related factors if we intend to improve access of health care to IDUs infected with $\mathrm{HCV}$.

\section{Limitations}

There are limitations in the present study. First, participation was voluntary and there may be bias associated with this approach. Although the response rate was higher than in other studies, it was
TABLE 1

Sociodemographic characteristics of hepatitis $\mathrm{C}$ health care providers $(n=169)$

\begin{tabular}{|c|c|c|c|c|}
\hline \multirow[b]{2}{*}{ Variable } & \multicolumn{2}{|c|}{ DIPs (n=73) } & \multicolumn{2}{|c|}{ CSPs $(n=96)$} \\
\hline & $\mathbf{n}$ & $\%$ & $\mathbf{n}$ & $\%$ \\
\hline \multicolumn{5}{|l|}{ Region (Canada) } \\
\hline Atlantic* & 4 & 5.48 & 13 & 13.54 \\
\hline Central $^{\dagger}$ & 41 & 56.16 & 45 & 46.88 \\
\hline Prairies ${ }^{\ddagger}$ & 24 & 32.88 & 12 & 12.50 \\
\hline Western ${ }^{\S}$ & 4 & 5.48 & 26 & 27.08 \\
\hline \multicolumn{5}{|l|}{ Physician type } \\
\hline Gastroenterologist & 35 & 47.95 & 53 & 55.21 \\
\hline $\begin{array}{l}\text { Infectious diseases } \\
\text { specialist }\end{array}$ & 35 & 47.95 & 22 & 22.92 \\
\hline Hepatologist & 3 & 4.11 & 21 & 21.88 \\
\hline \multicolumn{5}{|l|}{ Age group, years } \\
\hline$<39$ & 22 & 30.14 & 15 & 15.63 \\
\hline $40-49$ & 29 & 39.73 & 40 & 41.67 \\
\hline $50-59$ & 16 & 21.92 & 28 & 29.17 \\
\hline$\geq 60$ & 6 & 8.22 & 12 & 12.50 \\
\hline Missing data & 0 & 0.00 & 1 & 1.04 \\
\hline \multicolumn{5}{|l|}{ Sex } \\
\hline Male & 48 & 65.75 & 78 & 81.25 \\
\hline Female & 24 & 32.88 & 17 & 17.71 \\
\hline Missing data & 1 & 1.37 & 1 & 1.04 \\
\hline \multicolumn{5}{|l|}{ Years in practice } \\
\hline$<5$ & 15 & 20.55 & 7 & 7.29 \\
\hline $5-9$ & 12 & 16.44 & 18 & 18.75 \\
\hline 10-19 & 24 & 32.88 & 37 & 38.54 \\
\hline$\geq 20$ & 19 & 26.03 & 33 & 34.38 \\
\hline Missing data & 3 & 4.11 & 1 & 1.04 \\
\hline \multicolumn{5}{|c|}{ Population of practice community } \\
\hline$\leq 25,000$ & 0 & 0.00 & 2 & 2.08 \\
\hline$>25,000$ to $<100,000$ & 3 & 4.11 & 6 & 6.25 \\
\hline$\geq 100,000$ to $<500,000$ & 13 & 17.81 & 42 & 43.75 \\
\hline$\geq 500,000$ & 57 & 78.08 & 45 & 46.88 \\
\hline Missing data & 0 & 0.00 & 1 & 1.04 \\
\hline \multicolumn{5}{|l|}{ Practice type } \\
\hline Solo & 11 & 15.07 & 44 & 45.83 \\
\hline Not solo & 62 & 84.93 & 52 & 54.17 \\
\hline
\end{tabular}

*Includes New Brunswick, Newfoundland and Labrador, Nova Scotia and Prince Edward Island; 'Includes Quebec and Ontario; ${ }^{\ddagger}$ Includes Alberta, Saskatchewan and Manitoba; ${ }^{\S}$ British Columbia. CSPs Comprehensive service providers; DIPS Diagnostic investigative providers

lower than desired. We tried to improve the response rate and reduce respondent and nonrespondent bias by sending a prenotification card about the study and reminding the specialists to reply.

To understand the possible reasons of nonresponse and estimate the magnitude of biases associated with it, the nonrespondents were reassessed. From the initial list of 562 physicians, 25 were deemed ineligible for the study due to the following reasons: return to sender (ie, moved or did not treat HCV patients); e-mailed to state that they did not treat HCV patients; or that they had retired. After the follow-up telephone call, nine physicians were found to be ineligible for the following reasons: did not treat HCV patients; no time to complete the survey; moved; on holiday; or on maternity leave. We conducted a post hoc telephone survey of a group of nonresponders $(n=36)$. Unfortunately, we encountered several obstacles when telephoning: the phone number provided by the Canadian Medical Directory was a hospital and not a direct line to the physician; voice mail boxes were often full, so messages could not be left; and physicians were rarely spoken to directly. We suspect that a substantial number of the 
TABLE 2

Characteristics of health care providers associated with providing treatment to current injection drug users infected with hepatitis $\mathrm{C}$ virus

\begin{tabular}{|c|c|c|c|c|c|c|}
\hline & \multicolumn{2}{|c|}{ Treatment, n (row \%) } & \multicolumn{2}{|c|}{ Bivariate analysis } & \multicolumn{2}{|c|}{ Multivariate analysis* } \\
\hline & Provided & Not provided & OR $(95 \% \mathrm{Cl})$ & $\mathbf{P}$ & OR $(95 \% \mathrm{Cl})$ & $\mathbf{P}$ \\
\hline Total care providers & 19 (19.79) & $77(80.21)$ & & & & \\
\hline \multicolumn{7}{|l|}{ Region } \\
\hline Noncentral & 8 (15.69) & $43(84.31)$ & 1 & & 1 & \\
\hline Central & $11(24.44)$ & $34(75.56)$ & $1.74(0.63-4.80)$ & 0.2857 & $1.93(0.62-6.03)$ & 0.2574 \\
\hline \multicolumn{7}{|l|}{ Physician type } \\
\hline Noninfectious specialist & $11(14.86)$ & $63(85.14)$ & 1 & & 1 & \\
\hline Infectious specialist & $8(36.36)$ & $14(63.64)$ & 3.27 (1.11-9.63) & 0.0313 & $2.48(0.72-8.58)$ & 0.1512 \\
\hline \multicolumn{7}{|l|}{ Age group, years } \\
\hline$<50$ & $13(23.21)$ & $43(76.79)$ & 1 & & 1 & \\
\hline$\geq 50$ & $6(15.00)$ & $34(85.00)$ & $0.58(0.20-1.70)$ & 0.3226 & $0.48(0.12-1.88)$ & 0.2924 \\
\hline \multicolumn{7}{|l|}{ Sex } \\
\hline Male & 15 (18.99) & $64(81.01)$ & 1 & & 1 & \\
\hline Female & $4(23.53)$ & $13(76.47)$ & $1.31(0.38-4.60)$ & 0.7742 & $0.98(0.24-4.01)$ & 0.9727 \\
\hline \multicolumn{7}{|l|}{ Years in practice } \\
\hline$<10$ & $5(20.00)$ & $20(80.00)$ & 1 & & 1 & \\
\hline$\geq 10$ & $14(19.72)$ & $57(80.28)$ & $0.98(0.31-3.08)$ & 0.9757 & $1.64(0.39-6.83)$ & 0.4977 \\
\hline \multicolumn{7}{|c|}{ Population of practice community } \\
\hline$<500,000$ & $5(9.80)$ & $46(90.20)$ & 1 & & 1 & \\
\hline$\geq 500,000$ & $14(31.11)$ & $31(68.89)$ & $4.16(1.36-12.71)$ & 0.0125 & $3.89(1.06-14.26)$ & 0.0403 \\
\hline \multicolumn{7}{|l|}{ Solo practice } \\
\hline No & $14(26.92)$ & 38 (73.08) & 1 & & 1 & \\
\hline Yes & $5(11.36)$ & 39 (88.64) & $0.34(0.11-1.03)$ & 0.0573 & $0.70(0.18-2.73)$ & 0.6030 \\
\hline
\end{tabular}

*Adjusted for region, physician type, age group, sex, years in practice and size of community where they practice and solo practice

TABLE 3

Characteristics of health care providers associated with providing treatment to a person with a history of substance abuse/use who is stable on substitution therapy

\begin{tabular}{|c|c|c|c|c|}
\hline & \multicolumn{2}{|c|}{ Treatment, n (row \%) } & \multicolumn{2}{|c|}{ Bivariate analysis } \\
\hline & Provided & $\begin{array}{c}\text { Not } \\
\text { provided }\end{array}$ & $\begin{array}{c}\text { OR } \\
(95 \% \mathrm{Cl})\end{array}$ & $\mathbf{P}$ \\
\hline Total care providers & $86(89.58)$ & $10(10.42)$ & & \\
\hline \multicolumn{5}{|l|}{ Region } \\
\hline Noncentral & $47(92.16)$ & $4(7.84)$ & 1 & \\
\hline Central & $39(86.67)$ & $6(13.33)$ & $0.55(0.15-2.10)$ & 0.3845 \\
\hline \multicolumn{5}{|l|}{ Physician type } \\
\hline Noninfectious specialist & $65(87.84)$ & $9(12.16)$ & 1 & \\
\hline Infectious specialist & $21(95.45)$ & $1(4.55)$ & $2.91(0.35-24.30)$ & 0.3247 \\
\hline \multicolumn{5}{|l|}{ Age group, years } \\
\hline$<50$ & $48(85.71)$ & $8(14.29)$ & 1 & \\
\hline$\geq 50$ & $38(95.00)$ & $2(5.00)$ & $3.17(0.64-15.79)$ & 0.1589 \\
\hline \multicolumn{5}{|l|}{ Sex } \\
\hline Male & $71(89.87)$ & $8(10.13)$ & 1 & \\
\hline Female & $15(88.24)$ & $2(11.76)$ & $0.85(0.16-4.38)$ & 0.8412 \\
\hline \multicolumn{5}{|l|}{ Years in practice } \\
\hline$<10$ & $20(80.00)$ & $5(20.00)$ & 1 & \\
\hline$\geq 10$ & $66(92.96)$ & $5(7.04)$ & $3.30(0.87-12.56)$ & 0.0800 \\
\hline \multicolumn{5}{|c|}{ Population of practice community } \\
\hline$<500,000$ & $47(92.16)$ & $4(7.84)$ & 1 & \\
\hline$\geq 500,000$ & $39(86.67)$ & $6(13.33)$ & $0.55(0.15-2.10)$ & 0.3845 \\
\hline \multicolumn{5}{|l|}{ Solo practice } \\
\hline No & $46(88.46)$ & $6(11.54)$ & 1 & \\
\hline Yes & $40(90.91)$ & $4(9.09)$ & $1.30(0.34-4.95)$ & 0.6963 \\
\hline
\end{tabular}

nonrespondents were either ineligible or never received our study questionnaires. Furthermore, there was no reason to suspect that physicians treating HCV patients were less likely than those who were not to respond to this survey. Thus, the true adjusted response rate is likely higher than $42 \%$. Unfortunately, we did not have sufficient information to estimate the magnitude and direction of possible biases associated with nonparticipation.

Second, we only selected practitioners who were representative of the English-speaking specialists rather than all HCV-related health care providers. This reduced the number of eligible participants from 721 to 562 and, therefore, did not provide a complete examination of HCV health care services and pathways throughout Canada, and Quebec in particular. Furthermore, the Territories (Nunavut, Yukon and the Northwest Territories) were excluded from the study, thus limiting the examination of geographical variation. Third, only 96 specialists stated that they had a role in providing treatment; therefore, the sample size was relatively small. In addition, the data obtained from the surveys were self-reported and comprises the respondents' estimates of the HCV-management conditions in their practice and their own behaviours, which were possibly inaccurate. We restricted the study to a limited number of specialists' demographic factors and did not completely explore the role of all potential patient- and diseaserelated factors.

Finally, we are aware that the Canadian consensus statement (12) was published shortly after our study was conducted. Thus, our study results cannot be interpreted as a measure of physicians' adherence to the current guideline. Given the importance of this topic, it is necessary to track change of physicians' attitudes and practice over time.

\section{CONCLUSIONS AND FUTURE DIRECTIONS}

The attitudes of the physicians surveyed in the present study revealed a reluctance to provide HCV treatment to IDUs - even if they use a needle exchange. These findings emphasize the need for future research and delivery of services that address the complexity of care and treatment for people in marginalized social circumstances. 
Provision of services to $\mathrm{HCV}$-infected substance users is a challenge and requires the integration of members of a comprehensive care team, which can comprise hepatologists, psychologists, psychiatrists, IDs, immunologists, nurse practitioners, and drug and alcohol addiction counsellors. However, an ideal HCV health care practice would demand that we adjust provision of care to take into account the subculture of IDUs to more effectively deliver treatment to HCV-infected IDUs, thus helping to limit and reduce the spread of disease.

To obtain a complete account of HCV treatment in Canada, future studies need to evaluate the entire comprehensive care system that provides treatment to people living with HCV. It was suggested that adherence to antiviral therapy would be increased if patients were enrolled in multidisciplinary programs in which there is collaboration between areas, such as addiction counselling and hepatology, to allow for thorough patient follow-up by the comprehensive care team (18). However, there is

\section{REFERENCES}

1. Mathei C, Buntinx F, van Damme P. Seroprevalence of hepatitis C markers among intravenous drug users in western European countries: A systematic review. J Viral Hepat 2002;9:157-73.

2. Alter MJ, Kruszon-Moran D, Nainan OV, et al. The prevalence of hepatitis C virus infection in the United States, 1988 through 1994. N Engl J Med 1999;341:556-62.

3. Crofts N, Jolley D, Kaldor J, van Beek I, Wodak A. Epidemiology of hepatitis $\mathrm{C}$ virus infection among injecting drug users in Australia. J Epidemiol Community Health 1997;51:692-7.

4. Edlin BR. Prevention and treatment of hepatitis $\mathrm{C}$ in injection drug users. Hepatology 2002;36(5 Suppl 1):S210-9.

5. Backmund M, Meyer K, Von Zielonka M, Eichenlaub D. Treatment of hepatitis $\mathrm{C}$ infection in injection drug users. Hepatology 2001;34:188-93.

6. Grebely J, Raffa JD, Meagher C, et al. Directly observed therapy for the treatment of hepatitis $\mathrm{C}$ virus infection in current and former injection drug users. J Gastroenterol Hepatol 2007;22:1519-25.

7. Sylvestre DL, Litwin AH, Clements BJ, Gourevitch MN. The impact of barriers to hepatitis $C$ virus treatment in recovering heroin users maintained on methadone. J Subst Abuse Treat 2005;29:159-65.

8. Hagan H, Latka MH, Campbell JV, et al. Eligibility for treatment of hepatitis $\mathrm{C}$ virus infection among young injection drug users in 3 US cities. Clin Infect Dis 2006;42:669-72.

9. Strathdee SA, Latka M, Campbell J, et al. Factors associated with interest in initiating treatment for hepatitis $\mathrm{C}$ virus (HCV) infection among young $\mathrm{HCV}$-infected injection drug users. Clin Infect Dis 2005;40(Suppl 5):S304-12.

10. Nunes D, Saitz R, Libman H, Cheng DM, Vidaver J, Samet JH. Barriers to treatment of hepatitis $\mathrm{C}$ in $\mathrm{HIV} / \mathrm{HCV}$-coinfected adults with alcohol problems. Alcohol Clin Exp Res 2006;30:1520-6.

11. Doab A, Treloar C, Dore GJ. Knowledge and attitudes about treatment for hepatitis $\mathrm{C}$ virus infection and barriers to treatment among current injection drug users in Australia. Clin Infect Dis 2005;40(Suppl 5):S313-20.

12. Sherman M, Shafran S, Burak K, et al. Management of chronic hepatitis C: Consensus guidelines. Can J Gastroenterol 2007;21(Suppl C):25C-34C.

13. MDSelect: Canadian Medical Directory. <http://www.mdselect.com/> (Accessed on November 30, 2010).

14. Parkes J, Roderick P, Bennett-Lloyd B, Rosenberg W. Variation in hepatitis $\mathrm{C}$ services may lead to inequity of heath-care provision: A survey of the organisation and delivery of services in the United Kingdom. BMC Public Health 2006;6:3.

15. Falck-Ytter Y, Kale H, Mullen KD, Sarbah SA, Sorescu L, McCullough AJ. Surprisingly small effect of antiviral treatment in patients with hepatitis C. Ann Intern Med 2002;136:288-92.

16. Grebely J, Raffa JD, Lai C, et al. Low uptake of treatment for hepatitis $\mathrm{C}$ virus infection in a large community-based study of inner city residents. J Viral Hepat 2009;16:352-8. no evidence that physicians who are a part of a multidisciplinary team are more likely to provide treatment to HCV-infected IDUs than those in solo practice. For this reason, a more encompassing study needs to be conducted to examine the effectiveness of an integrated multidisciplinary HCV clinic and how it affects treatment uptake in the HCV-infected IDU population.

ACKNOWLEDGEMENTS: The authors thank all those who took part in the national survey, and the National Canadian Research Training Program in Hepatitis C and Atlantic Interdisciplinary Research Network for their support and funding. Angelique Myles was a recipient of the National Canadian Research Training Program in Hepatitis C Trainee Award and Atlantic Interdisciplinary Research Network studentship.

17. Cournot M, Glibert A, Castel F, et al. Management of hepatitis C in active drugs users: Experience of an addiction care hepatology unit. Gastroenterol Clin Biol 2004;28:533-9.

18. Robaeys G, Van Vlierberghe H, Mathei C, Van Ranst M, Bruckers L, Buntinx F. Similar compliance and effect of treatment in chronic hepatitis $\mathrm{C}$ resulting from intravenous drug use in comparison with other infection causes. Eur J Gastroenterol Hepatol 2006;18:159-66.

19. Van Thiel DH, Anantharaju A, Creech S. Response to treatment of hepatitis $\mathrm{C}$ in individuals with a recent history of intravenous drug abuse. Am J Gastroenterol 2003;98:2281-8.

20. Jeffrey GP, MacQuillan G, Chua F, et al. Hepatitis C virus eradication in intravenous drug users maintained with subcutaneous naltrexone implants. Hepatology 2007;45:111-7.

21. Rosenblum L, Darrow W, Witte J, et al. Sexual practices in the transmission of hepatitis B virus and prevalence of hepatitis delta virus infection in female prostitutes in the United States. JAMA 1992;267:2477-81.

22. Stephenson J. Former addicts face barriers to treatment for HCV. JAMA 2001;285:1003-5.

23. Loftis JM, Matthews AM, Hauser P. Psychiatric and substance use disorders in individuals with hepatitis C: Epidemiology and management. Drugs 2006;66:155-74.

24. Adeyemi OM, Jensen D, Attar B, et al. Hepatitis C treatment eligibility in an urban population with and without HIV coinfection. AIDS Patient Care STDS 2004:18:239-45.

25. National Institutes of Health Consensus Development Conference Panel statement. Management of Hepatitis C. Hepatology (Baltimore): National Institutes of Health, 1997.

26. Edlin BR, Kresina TF, Raymond DB, et al. Overcoming barriers to prevention, care, and treatment of hepatitis $\mathrm{C}$ in illicit drug users. Clin Infect Dis 2005;40(Suppl 5):S276-85.

27. Wang P, Yi Q, Scully L, Heathcote J, Krahn M. Indications for interferon/ribavirin therapy in hepatitis $\mathrm{C}$ patients: Findings from a survey of Canadian hepatologists. Can J Gastroenterol 2003;17:183-6.

28. Grebely J, Petoumenos K, Matthews GV, et al. Factors associated with uptake of treatment for recent hepatitis $\mathrm{C}$ virus infection in a predominantly injecting drug user cohort: The ATAHC Study. Drug Alcohol Depend 2010;107:244-9.

29. Seal KH, Currie SL, Shen H, et al. Hepatitis C treatment candidacy and outcomes among 4318 US veterans with chronic hepatitis C virus infection: Does a history of injection drug use matter? J Clin Gastroenterol 2007;41:199-205.

30. Grebely J, Genoway KA, Raffa JD, et al. Barriers associated with the treatment of hepatitis $C$ virus infection among illicit drug users. Drug Alcohol Depend 2008;93:141-7.

31. Stein MD, Maksad J, Clarke J. Hepatitis C disease among injection drug users: Knowledge, perceived risk and willingness to receive treatment. Drug Alcohol Depend 2001;61:211-5. 


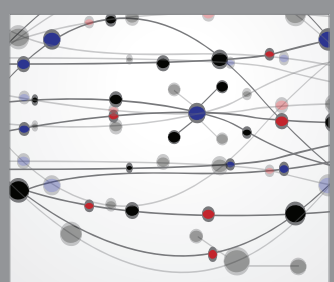

The Scientific World Journal
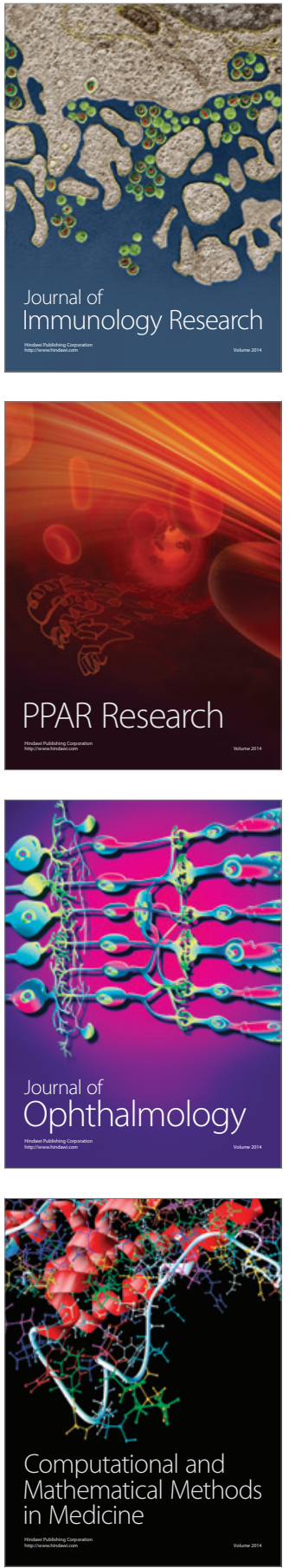

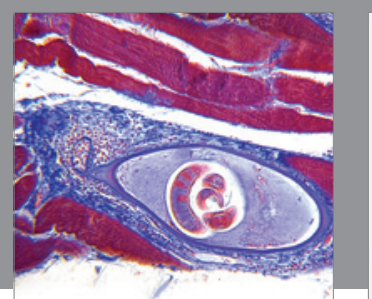

Gastroenterology Research and Practice

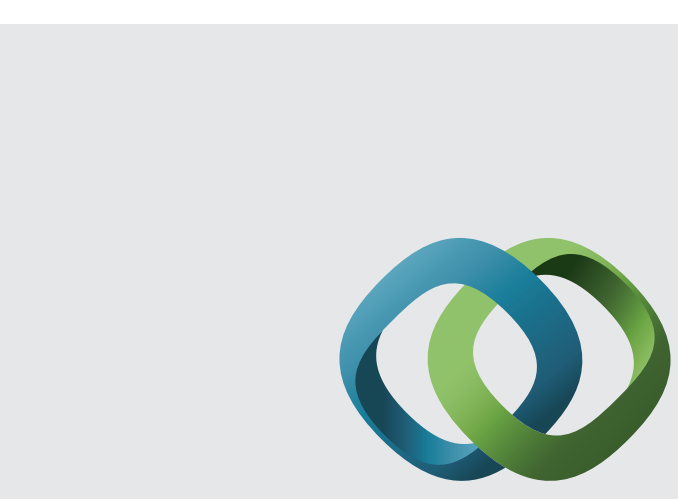

\section{Hindawi}

Submit your manuscripts at

http://www.hindawi.com
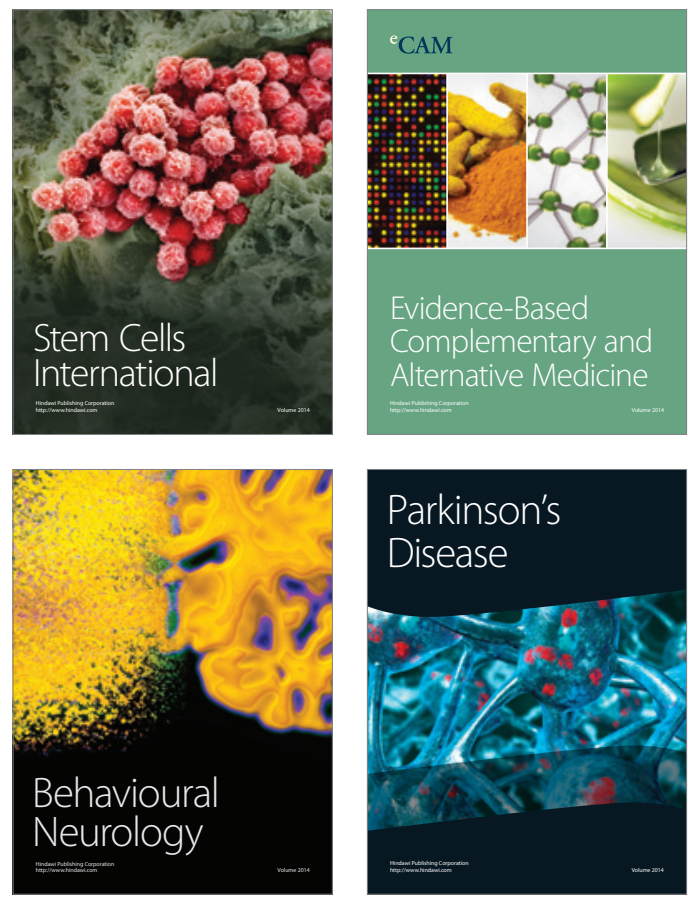
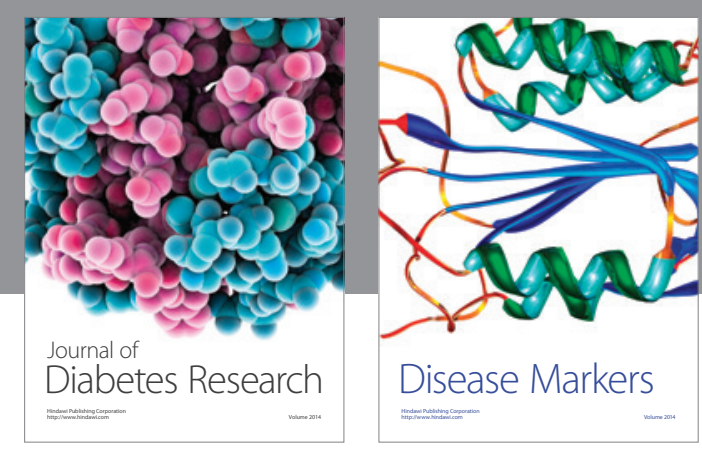

Disease Markers
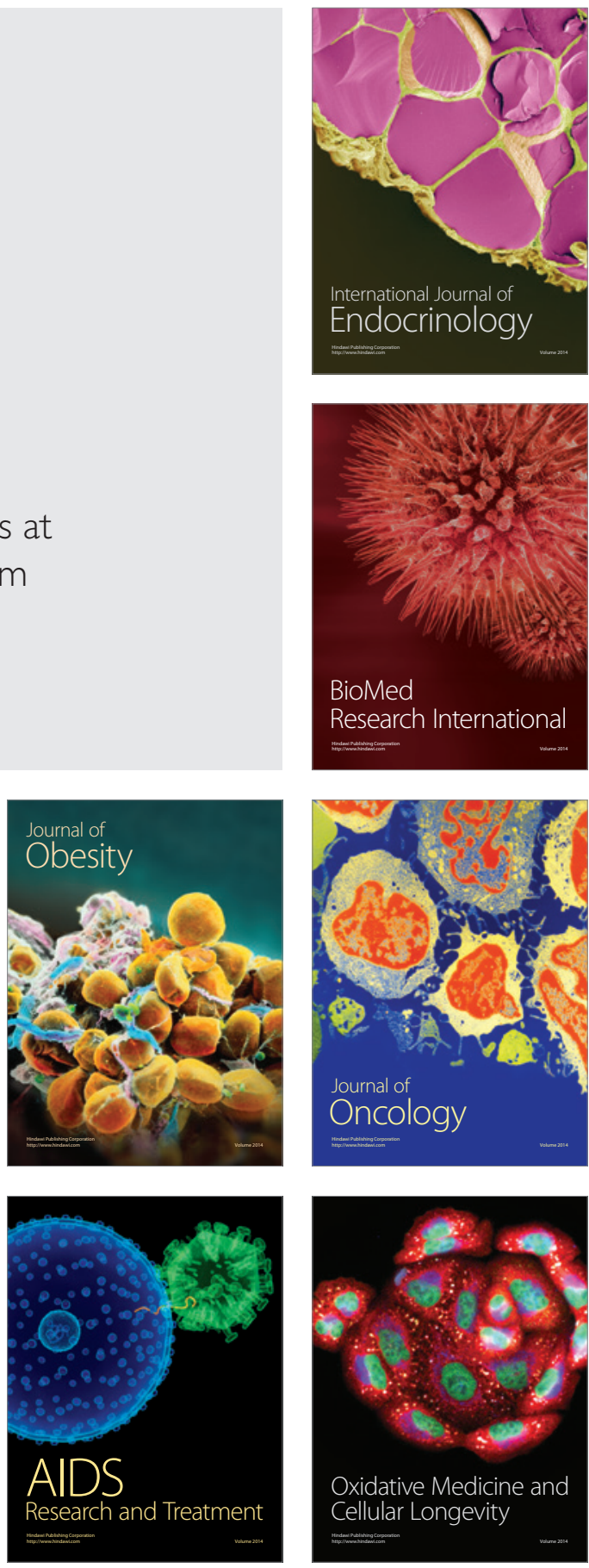